\title{
BACTERIAL DIVERSITY OF THE DEEP SEA OF SANGIHE TALAUD, SULAWESI
}

\section{Keanekaragaman Bakteri Laut Dalam Sangihe Talaud, Sulawesi}

\author{
Gintung Patantis ${ }^{1)}$, Ekowati Chasanah"1), Dewi Seswita Zilda'), and Ikhsan B. Waluyo') \\ 1) Research and Development Center for Marine and Fisheries Product Processing and Biotechnology \\ 2) The Agency for The Assessment and Application of Technology (BPPT), Jl. MH. Thamrin 8 Jakarta \\ *Correspondence author: Gintung Patantis, KS. Tubun Petamburan VI Jakarta Pusat 10260, E-mail: gintung_p@yahoo.com
}

\begin{abstract}
Deep sea is an extreme environment characterized by cold temperature, high pressure, lack of light and nutrients. Microorganisms live in these habitat are unique microorganisms and known to have tremendous source of potential agents for biotechnology processes. Indonesia as an archipelagic country has a vast deep ocean. This study aims to see the diversity of bacteria in Sangihe Talaud Deep Sea, Sulawesi. Analysis of bacterial diversity was carried out by cultured and uncultured method. Terminal Restriction Fragment Length Polymorphism (T-RFLP) technique was used for uncultured analysis of the microorganisms biodiversity, while cultured one was done by plating the samples of water onto Zobell media. The results showed that, there were 21 isolates obtained by cultured method. The identification which based on $16 \mathrm{~S}$ rDNA by PCR method showed the genus of Pseudomonas, Pseudoalteromonas, Alteromonas, Vibrio, Shewanella and Uncultured bacterium were identified. However, 14 classes of bacteria were obtained by using TRFLP method i.e Acetobacteraceae class, Actinobacteria, $\alpha$-proteobacteria, $\beta$-proteobacteria, $\delta$ proteobacteria, Y-proteobacteria, Bacili, Bacteroidetes, Chlorobi, Chroococcales, Clostridia, Erysipelotrichi, Synergistia, and Zetaproteobacteria. There were also unclassified bacteria and uncultured bacterium found in the samples.
\end{abstract}

Keywords: deep sea, diversity, bacteria, PCR, T-RFLP, Sangihe Talaud

\begin{abstract}
ABSTRAK
Laut dalam merupakan lingkungan ekstrim yang dicirikan oleh suhu dingin, tekanan tinggi, cahaya dan nutrien yang kurang. Mikroorganisme yang hidup pada habitat tersebut merupakan mikroorganisme yang unik dan diketahui mempunyai potensi bioteknologi yang sangat besar. Indonesia sebagai negara kepulauan mempunyai laut dalam yang luas. Penelitian ini bertujuan untuk melihat keanekaragaman bakteri yang ada di laut dalam Sangihe Talaud, Sulawesi. Analisis keragaman bakteri dilakukan dengan metode kultur dan uncultured. Teknik Terminal Restriction Fragment Length Polymorphism (T-RFLP) digunakan untuk analisis keragaman mikroorganisme secara uncultured, sedangkan analisis kultur dilakukan dengan menumbuhkan sampel air pada media Zobell. Hasil penelitian menunjukkan bahwa dengan teknik kultur didapatkan 21 isolat. Identifikasi dengan PCR $16 \mathrm{~S}$ rDNA menunjukkan genus Pseudomonas, Pseudoalteromonas, Alteromonas, Vibrio, Shewanella dan Uncultured bacterium. Sebanyak 14 kelas didapatkan dengan teknik T-RFLP, yaitu : kelas Acetobacteraceae, Actinobacteria, $\alpha-$ proteobacteria, $\beta$-proteobacteria, $\delta$-proteobacteria, $y$-proteobacteria, Bacili, Bacteroidetes, Chlorobi, Chroococcales, Clostridia, Erysipelotrichi, Synergistia, dan Zetaproteobacteria. Hasil identifikasi juga menemukan bakteri yang tidak terklasifikasi dan bakteri yang tidak dapat dikultur.
\end{abstract}

Kata Kunci: laut dalam, keanekaragaman, bakteri, PCR, T-RFLP, Sangihe Talaud

\section{INTRODUCTION}

Deep sea is an extreme environment characterized by high pressure (up to 110 megapascals (MPa), lack of light and nutrients and dominated by low temperature $\left(0-4^{\circ} \mathrm{C}\right)$, except at hydrothermal vents region where the temperature is elevated (up to 375$400^{\circ} \mathrm{C}$ ) (Kato \& Qureshi, 1999; Li et al., 1999; 
Radjasa, 2004). Microorganisms which live in extreme environment have a specific capability to adapt. Barophiles and piezophiles are microorganisms which are capable to adapt on high pressure environment, psycrophiles is well adapted on low temperature, and thermophiles is microorganism which live in elevated temperature environment (Kato et al., 1995; De long et al., 1997; Dobbs \& Selph, 1997).

Microorganisms play an important role on biochemistry cycle in the sea and have a huge biotechnology potential such as enzymes or secondary metabolites sources of novel natural products, including lipids, pigments, pharmaceuticals and low and high temperature adapted enzymes (Radjasa, 2004; Ferer et al., 2005; Parliamentary Office of Science and Technology, 2007).

Although there have been many studies conducted to determine the bacterial diversity in the deep ocean from various places such as Northwestern Pacific Ocean (Radjasa et al., 2001); Southwestern Pacific Ocean (Radjasa, 2001); West Pacific (Zeng et al., 2004); Nankai Trough (Li et al., 1999; Toffin et al., 2004); Japan Trench (Kato et al., 1999; Maruyama et al., 2000); Mariana Trench (Yayanos et al., 1981; Takami et al., 1997; Pathom-aree et al., 2006); North Atlantic (Sogin et al., 2006); Eastern Tropical Atlantic (Rueger \& Tan, 1992); Eastern Mediterranean (Heijs et al., 2008; Polymenakou et al., 2009), only few are reported about bacterial diversity from Indonesia Waters (Nasima et al., 2008).

Indonesia as an archipelagic country has about $81,000 \mathrm{~km}$ of coastline and 5.8 million $\mathrm{km}^{2}$ of marine area including vast deep oceans such as Halmahera, Banda and Sulawesi Trenches. Exploring the richness of deep-sea microbial population from Indonesian Deep Sea environments is a great challenge that will require not only human resources but also knowledge in the area of deep sea microbiology, institutional capacity, and popular support (Radjasa, 2004). This research has been done by using two approaches, i.e. cultured and uncultured methods.

Cultured methods have a limitation in which only $1 \%$ of bacteria can be cultured in laboratory, while uncultured methods are able to determine the most of bacteria living in a certain environment. Due to this reason, the uncultured methods are frequently used to measure the biodiversity of bacteria (Amann et al., 1995). Among the uncultured methods, terminal restriction fragment length polymorphism (T-RFLP) is considerable technique used to study microbial diversities (Schutte et al., 2008). T-RFLP analysis is a method to study complex microbial communities based on variation in the 16S rRNA gene (Osborn et al., 2001). It was used to determine the pattern of the bacteria from various environments (Nakano et al., 2008) and bacterial dynamics in response to environmental changes (Osborn et al., 2001). Some of the advantages of this method are low cost and able to analyze hundred of samples per day (Zhang et al., 2008). This method was also used for monitoring the changes of bacterial communities in the water column (Zhang et al., 2008) and sediments (Yoza et al., 2007).

This research is a part of collaboration research between Indonesia and USA named INDEX SATAL expedition 2010. This study aimed to see the diversity of bacteria in Sangihe Talaud Deep Sea, Sulawesi, by cultured and uncultured methods using T-RFLP analysis.

\section{MATERIALS AND METHOD}

\section{Sample Collection and Preparation}

The seawaters were collected from 3 locations of Sangihe Talaud Waters, North Sulawesi, Indonesia (Figure 1) during INDEX SATAL 2010 Cruise on R/V Baruna Jaya IV. Samples were collected by using water samplers attached with Conductivity Temperature Depth (CTD). CTD is the primary tool for determining essential physical properties of sea water. It is used to measure water temperature, salinity, and density. Sterile bottle was used to collect water sample for bacteria isolation. Approximately 8 liters of water from each sample sites was sequentially filtered through $0.22 \mu \mathrm{m}$ pore-size filters paper. The filters were then placed in the bottle containing sterilized sea water and stored at $-20^{\circ} \mathrm{C}$ until being analyzed in laboratory.

\section{Isolation and Identification of Cultured Bacteria}

Bacteria was grown on Zobell media ( $2.5 \mathrm{~g}$ peptone; $0.5 \mathrm{~g}$ yeast extract per 1 liter seawater) and incubated at $8^{\circ} \mathrm{C}$. The bacterial genomic DNA was extracted from a fresh cell culture (48 $h$ ) using the Genomic DNA Purification Kit (Fermentas) according to the manufacturer's instructions, with the addition of Iysozim and proteinase-K. 16S rRNA genes of bacteria were amplified by PCR using universal primers 63-F (5'-CAGGCCTAACACAGGCAAGTC-3') and 1387-R (5'-GGGCGGWGTGTACAAGGC-3'). The PCR products were then purified with QIA quick PCR Purification Kit as manufacture's instruction (Qiagen, Germany). DNAs were sequenced in $1^{\text {st }}$ Base Laboratory, Singapore. Sequences were compared with the sequences from NCBI databases using the BLAST (Basic Local Alignment Search Tool) program (Altschul et al., 1990) to find the closest homologues 


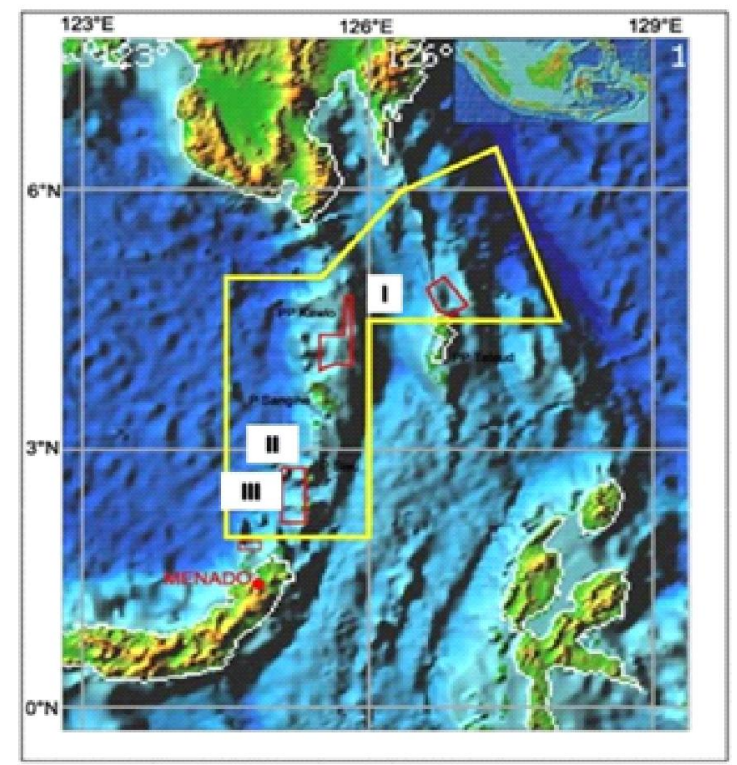

Figure 1. Sampling location at Sangihe Talaud, North Sulawesi (site I, II, and III).

with the sequences retrieved from the GenBank database available at the NCBI website (http://www. ncbi. nIm. nih.gov/).

\section{DNA Extraction of Bacterial Community}

The method for DNA extraction was modified from Zhou et al. (1996). Filter papers placed in the bottle containing sterilized sea water were cut and returned back to the bottle, then vortexed at full speed for 10 min; the supernatant was transferred into a sterile micro tube then centrifuged at $10,000 \times \mathrm{g}$ for $5 \mathrm{~min}$. The pellets were added with $750 \mathrm{~mL}$ of extraction buffer and vortexed afterward at full speed for 2 min and centrifuged at $14,000 \times \mathrm{g}$ for $30 \mathrm{sec}$. The supernatant was frozen at $-80^{\circ} \mathrm{C}$ for $10 \mathrm{~min}$ and then thawed at $65^{\circ} \mathrm{C}$ (this step was done twice). The thawed supernatant was left at room temperature. About $5 \mu \mathrm{L}$ proteinase- $\mathrm{K}$ was added and incubated at $37^{\circ} \mathrm{C}$ for 30 min and then added with $150 \mathrm{~mL}$ sarkosyl. The solution was incubated at $65^{\circ} \mathrm{C}$ for $30 \mathrm{~min}$ (being inverted every $10 \mathrm{~min}$ ). After centrifugation at $10,000 \mathrm{x}$ g speed for $5 \mathrm{~min}$, supernatant was purified by phenol: chloroform: isoamyl alcohol (P:C:I) extraction solution with composition of 25:24:1. The mixture was centrifuged at $14,000 \times \mathrm{g}$ for $5 \mathrm{~min}$. Purification by $P: C: I$ were conducted twice. The supernatant was further purified by chloroform: isoamyl alcohol (24:1) and centrifuged at $14,000 \times \mathrm{g}$ for $5 \mathrm{~min}$. The DNA in supernatant was subsequently precipitated in cold absolute isopropanol and incubated at $-20^{\circ} \mathrm{C}$ for 30 $\mathrm{min}$. After centrifugation at $16,000 \times \mathrm{g}$ for $5 \mathrm{~min}$ at $4^{\circ} \mathrm{C}$, the DNA pellet was washed with $600 \mu \mathrm{L}$ cold ethanol $(70 \%)$. The mixture was centrifuged at 16,000 $\mathrm{xg}$ for $5 \mathrm{~min}$ and the obtained DNA was dried at $37^{\circ} \mathrm{C}$ for $10 \mathrm{~min}$ and diluted in $30 \mu \mathrm{L}$ of Tris- $\mathrm{Cl} \mathrm{pH} 810 \mathrm{mM}$. The DNA was purified using Wizard @ DNA Clean-Up System (Promega, USA) and frozen until being used.

\section{6s rDNAAmplification for T-RFLP}

16s-rRNA gene was amplified using polymerase chain reaction method (PCR) with universal primers 27F-FAM (5'-AGA GTT TGA TCC TGG CTC AG- 3') and 1387R (5'-GGG CGG WGT GTA CAA GGC-3') (Egert \& Friedrich 2003). The $25 \mu \mathrm{L}$ PCR reaction contained $12.5 \mu \mathrm{L}$ GoTaq Green Master mix, $1 \mu \mathrm{L}$ DNA template, $1 \mu \mathrm{L}$ primer $27 \mathrm{~F}$ and $1387 \mathrm{R}$ primers $(25 \mathrm{pmol} / \mu \mathrm{l})$, and $\mathrm{ddH}_{2} \mathrm{O}$. The PCR condition was set at $95^{\circ} \mathrm{C}$ for $5 \mathrm{~min}$, followed by 30 cycles of $95^{\circ} \mathrm{C}$ for 30 sec, $55^{\circ} \mathrm{C}$ for $30 \mathrm{sec}, 72^{\circ} \mathrm{C}$ for $1 \mathrm{~min}$, and $72^{\circ} \mathrm{C}$ for 10 min. The amplified DNA was verified by electrophoresis in $1 \%$ agarose in $1 \times$ TAE buffer.

\section{T-RFLP Analysis}

The fluorescently labeled PCR products were purified with QIAquick PCR Purification Kit (Qiagen, Germany) according to the manufacture's protocol. The purified amplicons were digested by using 3 different endonuclease restriction enzymes, Hpall, Rsal, and Bsh 1236I (BstUI). Digestion reaction was performed in a total volume of $30 \mu \mathrm{L}$ containing $24 \mu \mathrm{L}$ DNA samples, $3 \mu \mathrm{L}$ restriction enzymes, $3 \mu \mathrm{L} 10 \mathrm{x}$ restriction buffer. The mixture was incubated overnight at $37^{\circ} \mathrm{C}$.

DNA produced by digestion was run on the $A B I$ Prism DNA sequencing tool Avant 3100 Genetic Analyser (Applied Biosystem, USA) using GeneScan program (Applied Biosystem, USA) and GS 500 ROX 
Table 1. Location and characteristics of the sampling area

(Applied Biosystem, USA) as an internal marker. GeneScan analysis was conducted at The $1^{\text {st }}$ Base Laboratory, Singapore. Fragment sizes were analyzed using T-RFLP Fragment Sorter (FragSort) 5.0 software with database from Microbial Community Analysis (MiCA). FragSort data were arranged using Microsoft Excel 2007 and matched with Bergey's Manual $2^{\text {nd }}$ edition to find the class.

\section{RESULT AND DISCUSSION}

Sangihe Talaud is located in two districts namely Kepulauan Sangihe and Kepulauan Talaud, North Sulawesi Province. This area is the border between Indonesia and Philippines (Mindanao Island). Previous researches indicated that there were lots of volcanic activity both on the land and under the sea of Sangihe Talaud. There are 2 locations allegedly influencing the conditions in Sangihe Talaud Waters, Mount Karangetang which was erupted in 2010 and West Kawio, located $1,900 \mathrm{~m}$ below the sea with $3,500 \mathrm{~m}$ height and diameter reached $50 \mathrm{~km}$. Sampling locations are located in the island of Sangihe, Kawio and Siau. Sampling site characteristics were present in Table 1.

The depth of the sample collection was 699 to 1,000 meters. The data of the environment characteristics such as salinity, $\mathrm{DO}$ and $\mathrm{pH}$ were similar, but the temperature at site III was different from two other sites. It is due to the depth which only $699 \mathrm{~m}$ and it is located near the caldera which is likely to have a high temperature. Sogin et al. (2006) who took sample in North Atlantic Deep Water and Axial Seamount, Juan de Fuca Ridge found that the temperature at the depth of $1,400-4,121$ and 500 meters was ranged from 2.3 to $3.5^{\circ} \mathrm{C}$ and $7^{\circ} \mathrm{C}$ respectively, whereas in the seamount where the depth is around 1500 meters, the temperature reached $31.2^{\circ} \mathrm{C}$.

Result of analysis T-RFLP fragment from three locations showed variety in species, genus, and class of bacteria. The number of bacteria detected was very high $( \pm 2,900$ bacteria), therefore the data was displayed into the class. Overall, there were 14 classes of bacteria detected in deep sea of Sangihe Talaud. The classes of bacteria identified were Acetobacteraceae, Actinobacteria, a-proteobacteria, Bacilli, Bacteroidetes, $\beta$-proteobacteria, Chlorobi, Chroococcales, Clostridia, $\delta$-proteobacteria, Erysipelotrichia, y-proteobacteria, Synergistia, and Zetaproteobacteria. However there were also unclassified bacteria and uncultured bacterium found (Table 2.).

The highest bacterial community obtained was from sample site III which had a total number of 2,244 bacteria, followed by site I and II with 541 and 121 numbers of bacteria, respectively. Site III sample also showed the highest number of bacteria classes. There were 13 out of 14 classes found in this site. Abundant nutrient at seamount area was alleged as a cause of the higher bacteria diversity in this site compared to the other sites. The area of seamount is generally rich of nutrient such as carbon, methane, hydrogen, hydrogen sulfide, sulfur, iron and high manganese originated from the magma chambers (Winn et al., 1995; Gartner, 2011).

The microbial community in site III was dominated by Bacilli and Actinobacteria class which were not found in site I and II. Actinobacteria and Bacilli are commonly found in marine sediment, play an important role on the transformation and production of different biologically active compounds, and also involve in the manganese oxidation (Moran et al., 1995; Miranda et al., 2008). A number of Actinobacteria and Bacilli species are wellknown due to their ability to grow at elevated temperature (Kurup \& Fink, 1975; Edward, 1993; Song et al., 2001; Petrova \& Vlahov, 2007; Zilda et al., 2009). Geobacillus caldoproteolyticus, Thermomonospora chromogena, Thermobaculum terrenum, Thermoactinomyces vulgaris were found at site III. These species are belong 
Table 2. Classes of bacteria isolated from different sample sites

to Actinobacteria and Bacilli categorized as thermophilic bacteria.

There were several species that play a role on the cycle of sulfate, sulfite, sulfur, methyl found in this site such as: Desulfatimicrobium mahresensis, Desulfovibrio desulfuricans, Methylarcula marina, Methylobacillus flagellates, Methylotenera mobilis, Sulfitobacter sp., Sulfobacillus sp., and Sulfobacillus thermosulfidooxidan. $y$-proteobacteria were related to phylotypes involved in methane cycling and $\delta$ proteobacteria was grouped included in to sulphatereducers related to anaerobic oxidation of methane (AOM) (David et al., 2005; Pachiadaki et al., 2010).

There were some classes found in all locations such as $\alpha$-proteobacteria dan $\gamma$-proteobacteria. Several Proteobacteria phyla $\left(\alpha-, \delta-\right.$, and $\gamma^{-}$ proteobacteria classes) dominated in marine sediments associated with carbon and nitrogen cycles (Hunter et al., 2006; Pachiadaki et al., 2010). Rhodobacterales bacterium belonging to the class of a-proteobacteria that is known living in a low temperature and high pressure (Psychropiezophiles) were found in site II, while Aphanothece sp. (Chroococcales class) which are able to live in high salinity (halophiles) were found in site I (Sarma \& Arora, 2001; Eloe et al., 2011). There were types of Roseovarius sp. which is an oil degrader found in site I and III. This species is known able to degrade a wide range of hydrocarbons such as $\mathrm{C} 10-35$ which is potential for marine bioremediation (Harwati et al., 2007).

Pachiadaki et al. (2010) reported a diversity of bacteria of Kazan mud volcano, East Mediterranean Sea which found some classes of bacteria such as Acidobacteria, Actinobacteria, $\alpha$-proteobacteria, Bacteroidetes, $\beta$-proteobacteria, Chlorobi, Chloroflexi, $\delta$-proteobacteria, y-proteobacteria, Epsilon proteobacteria, Deferribacteres, Firmicutes, Fusobacteria, Planctomycetes, Spirochaetes. According to Takai et al. (2006) microbes that inhabit in the mountain areas of marine microbial groups are dominated by chemoautotrophic.

Due to the limited Alpha number of cultured bacteria, the samples were not grouped into sampling location. Twenty one isolates were obtained from the screening using Zobell medium with $2 \%$ agar incubated at $8^{\circ} \mathrm{C}$ for 7 days. All bacteria grown were identified based on 16S-rDNA. Phylogenetic analysis of $16 \mathrm{~S}$ rDNA of the isolates showed that many phenotypes in this waters were very similar. The analysis also showed that many sequences were almost identical one to another, suggesting that the bacteria community isolated in this deep sea waters were dominated by a few major groups (Table 3 and Fig. 2).

Five genus were obtained in this study, i.e Pseudoalteromonas, Alteromonas, Shewanela, Vibrio and Uncultured bacterium. The genus 
Table 3. Result of sequencing analysis of cultured bacteria

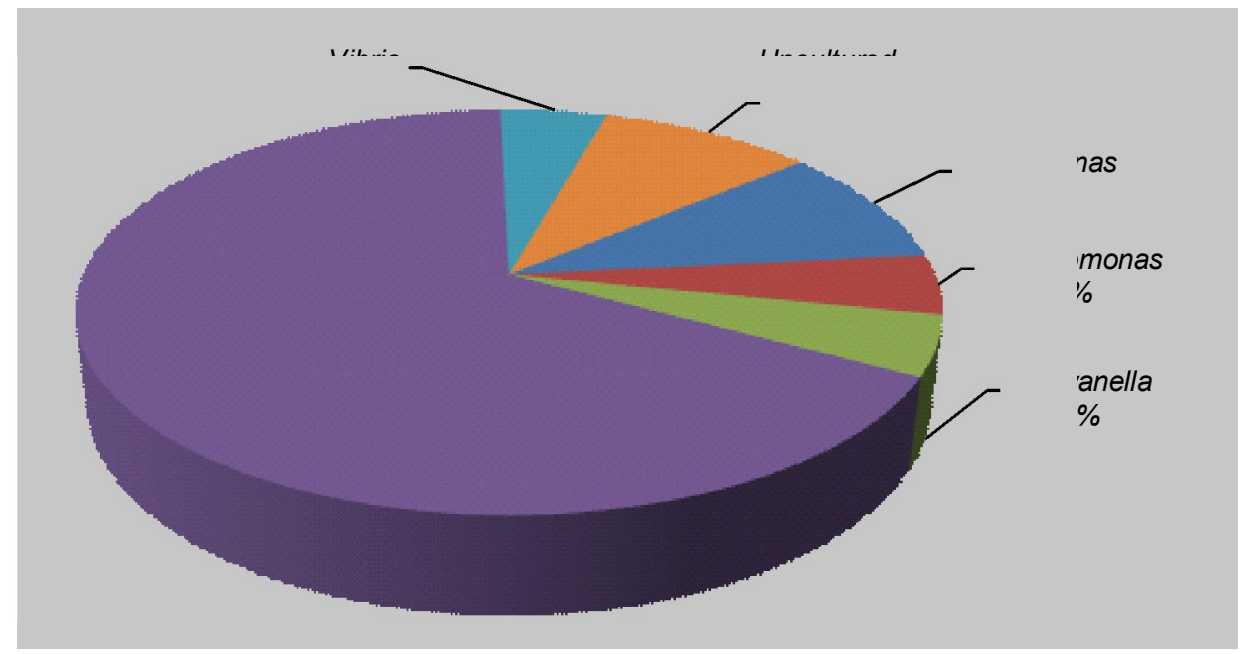

Figure 2. Group of the deep sea bacteria from Sangihe Talaud Waters.

Pseudoalteromonas was the most dominant group followed by Uncultured bacterium, Shewanela, Vibrio and Pseudomonas. Nasima et al. (2008) reported that Psychrobacter, Pseudomonas and Vibrio which are psychrotrophic bacteria were found in sea waters of Makasar Strait. While Zeng et al. (2004) also reported that psychrotrophic bacteria isolated from the deepsea sediments of West Pacific were affiliated to the 
Psychrobacter, Pseudoalteromonas, and Pseudomonas genera in the $\mathrm{y}$-Proteobacteria group. The member of genus Vibrio was also found in the present study. Pseudoalteromonas, and Vibrio, were common bacteria found in the surface and deep sea waters of the North-western Pacific. Overall, the members of Vibrionaceae appeared to be dominant in both habitats (Radjasa et al., 2001). Shewanella is also known to live at high pressure (barophiles) (De Long et al., 1997). There were 2 isolates found to be similar with uncultured bacteria (XA1 R and XI A4 F). Further identification using biochemical method should be done to ensure whether the isolates are novel species or not.

The results obtained from this study almost similar with previous studies both derived from Indonesian Waters or from waters outside Indonesia (Radjasa et al., 2001; Zeng et al., 2004; Nasima et al., 2008). According to Radjasa, (2004) and De Long et al., (1997) barophiles and psychrophiles bacteria can be grouped into several groups: Colwellia, Psychromonas, Shewanella, Photobacterium and Moritella.

The results showed that higher biodiversity was produced by uncultured method than cultured method. T-RFLP method could only describe the biodiversity based on comparison of the result of T-RFs with the data base. The complete result may be obtained by constructing library clone of $16 \mathrm{~S}$ gen from the environmental DNA.

\section{CONCLUSION}

There were 14 classes of bacteria found by uncultured method from 3 sampling locations i.e: Acetobacteraceae, Actinobacteria, $\alpha$-proteobacteria, $\beta$-proteobacteria, $\delta$-proteobacteria, $\gamma$-proteobacteria, Bacili, Bacteroidetes, Chlorobi, Chroococcales, Clostridia, Erysipelotrichi, Synergistia, Zetaproteobacteria. The result also found there were Unclassified bacteria and Uncultured bacterium. The highest bacterial community obtained from site III which had total of 2,244 number consisting of 13 classes of bacteria. However, only 21 isolates were found by cultured method. Identification using $16 \mathrm{~S} \mathrm{r}-$ DNA PCR, showed that bacterial diversity of Sangihe Talaud sea were identified as the genus of Pseudomonas, Pseudoalteromonas, Alteromonas, Vibrio, Shewanella and Uncultured bacterium.

\section{ACKNOWLEDGEMENT}

This work was partly supported by the INDEX SATAL 2010 project and Research Center for Marine \& Fisheries Product Processing \& Biotechnology, Ministry of Marine Affair and Fisheries. Special thanks to the Captain and crews of R/V Baruna Jaya VI, for their helps during the sampling.

\section{REFERENCES}

Altschul, S.F., Gish, W., Miller, W., Myers, E.W., and David J. Lipmanl, D.J. 1990. Basic local alignment search tool. J. Mol. Biol. 215: 40-410.

Amann, R.I., Ludwig, W., and Schleifer, K.H. 1995. Phylogenetic identification and in situ detection of individual microbial cells without cultivation. Microbiol. Rev. 59: 143-169.

David, R.B., Richard, W.C., George, M.G., Don, J.B., Noel, R.K., and James, T.S. 2005. Bergey's Manual of Systematic Bacteriology.

De Long, E.F., Franks, D.G., and Yayanos, A.A.1997. Evolutionary relationships of cultivated psychrophilic and barophilic deep-sea bacteria. Appl. Environ. Microbiol. 63: 2105-2108.

Dobbs, F.C. and Selph, K.A. 1997. Thermophilic bacterial activity in a deep-sea sediment from the Pacific Ocean. Aquat. Microb. Ecol. 13: 209-212.

Edward, C. 1993. Reviews in Biotechnology: Isolation properties and potential applications of thermophilic actinomycetes. Applied Biochemistry and Biotechnology. 42 (2-3): 161-179.

Eloe, E.A., Malfatti, F., Gutierrez, J., Hardy, K., Schmidt, W. E., Pogliano, K., Pogliano, J., Azam, F., and Bartlett, D.H. 2011. Isolation and characterization of a psychropiezophilic alphaproteobacterium. Applied and Environ. Microbiology. 7 (22): 8145-8153.

Ferrer, M., Golyshina, O.V., Chernikova, T.N., Khachane, A.N., Martins dos Santos, V.A.P., Yakimov, M.M., Timmis, K.N., and Golyshin, P.N. 2005. Microbial enzymes mined from the urania deep-sea hypersaline anoxic basin. J. Chem.Biol. 12: 895-904.

Gartner, A. 2011. Isolation and characterization of bacteria from the deep sea and their potential to produce bioactive natural products. Dissertation. University of Kiel. $151 \mathrm{pp}$.

Harwati, T.U., Kasai, Y., Kodama, Y., Susilaningsih, D., and Watanabe, K. 2007. Characterization of diverse hydrocarbon-degrading bacteria isolated from Indonesian seawater. Microb. Environ. 22(4): 412415.

Heijs, S.K., Laverman, A.M., Forney, L.J., Hardoim, P.R. and van Elsas, J.D. 2008. Comparison of deep-sea sediment microbial communities in the Eastern Mediterranean. FEMS Microbiol. Ecol. 64: 362-377.

Hunter, E.M., Mills, H.J., and Kostka, J.E. 2006. Microbial community diversity associated with carbon and nitrogen cycling in permeable shelf sediments. Appl Environ. Microbiol. 72 (9): 5689-5701.

Kato, C. and Qureshi, M.H. 1999. Pressure Response in Deep-sea Piezophilic Bacteria. J. Mol. Microbiol. Biotechnol. 1 (1): 87-92.

Kato, C., Sato, T., and Horikoshi, K. 1995. Isolation and properties of barophilic and barotolerant bacteria from deep-sea mud samples. Biodiv. Conserv. 4: 1-9. 
Kato, C., Yanagibayashi, M., Nogi, Y., and Horikoshi, K. 1999. Analyses of microbial diversity in the sediment obtained from Japan Trench at a depth of $7326 \mathrm{~m}$ and high pressure cultivation. JAMAREC J. Deep. Sea. Res. Biol. 15: 47-52.

Kurup, V.P. and Fink, J.N. 1975. A scheme for the identification of thermophilic actinomycetes associated with hypersensitivity pneumonitis. J. of Clinical Microbiol. 2 (1): 55-61.

Li, L., Kato, C., and Horikoshi, K. 1999. Microbial diversity in sediments collected from the deepest cold-seep area, the Japan Trench. Mar. Biotechnol. 1: 391-400.

Maruyama, A., Honda, D., Yamamoto, H., Kitamura, K., and Higashihara, T. 1997. Phylogenetic analysis of psychrophilic bacteria isolated from the Japan Trench, including a description of the deep-sea species Psychrobacter pacificensis sp. nov. International Journal of Systematic and Evolutionary Microbiology. 50: 835-846.

Miranda, C.A.C., Martins, O.B., and Clementino, M.M. 2008. Spesies-level identification of Bacillus strains isolates from marine sediments by conventional biochemical, 16S rRNA gene sequencing and intertRNA gene sequence lengths analysis. Antonie Van Leeuwenhoek. 93: 297-304.

Moran, M.A., Rutherford, L.T., and Hodson, R.E. 1995. Evidence for indigenous Streptomyces populations in a marine environment determined with a 16S rRNA probe. Appl. Environ. Microbiol. 61 (10): 3695-3700.

Nakano, Y., Takeshita, T., Kamio, N., Shiota, S., Shibata, Y., Yasui, M., and Yamashita, Y. 2008. Development and application of a T-RFLP data analysis method using correlation coefficient matrices. J. of Microbial Methods. 75: 501-505.

Nasima, D., Tsukamot, K.K., and Ohwada, K. 2008. Characterization of psychrotrophic bacteria from sea waters of Makasar Strait, Indonesia. J. of Coastal Development. 11 (3): 141-148.

Osborn, A.M., Moore, R.B. and Timmis, K.N. 2000. An evaluation of terminal-restriction fragment length polymorphism (T-RFLP) analysis for the study of microbial community structure and dynamics. Environ. Microbiol. 2 (1): 39-50.

Pachiadaki, M.G., Lykousis, V., Stefanou, E.G., and Kormas, K.A. 2010. Prokaryotic community structure and diversity in the sediments ofan active submarine mudvolcano (Kazanmudvolcano, East Mediterranean Sea). FEMS Microbiol. Ecol. 72: 429-444.

Parliamentary Office of Science and Technology. 2007. New industries in the deep sea. Postnote. 288: 1-4.

Pathom-aree, W., Stach, J., Ward, A., Horikoshi, K., Bull, A., and Goodfellow, M. 2006. Diversity of actinomycetes isolated from Challenger Deep sediment $(10.898 \mathrm{~m})$ from the Mariana Trench. Extremophiles. 10: 181-189.

Petrova, D. and Vlahov, S. 2007. Taxonomic characterization of the thermophilic actinomycete strain $21 \mathrm{e}-$ producer of thermostable collagenase. J. of Culture Collections 5: 3-9.
Polymenakou, P.N., Lampadariou, N., Mandalakis, M., and Tselepides, A. 2009. Phylogenetic diversity of sediment bacteria from the southern Cretan margin, Eastern Mediterranean Sea. Syst. Appl. Microbiol. 32: 17-26.

Radjasa, O.K. 2004. Deep-Sea Bacteria and Their Biotechnological Potential. J. Of Coastal Development 7 (3): 109-118.

Radjasa, O.K., Urakawa, H., Tsukamoto, K.K., and Ohwada, K. 2001. Characterization of psychrotrophic bacteria in the surface and deep-sea waters from northwestern Pacific Ocean based on $16 \mathrm{~S}$ ribosomal DNA approach. Mar. Biotechnol. 3: 454-46.

Radjasa, O.K. 2001. Occurrence of psychrophiles in cold deep sediments from Southwestern Pacific Ocean. Indon. J. Mar. Scie. 24: 283-287.

Rueger, H.J. and Tan, T.L. 1992. Community structures of cold and low-nutrient adapted heterotrophic sediment bacteria from the deep eastern tropical Atlantic. Mar. Ecol. Prog. Ser. 84: 83-93.

Sarma, S.D. and Arora, P. 2001. Halophiles. Encyclopedia of Life Sciences. p. 1-9.

Schütte, U.M.E., Abdo, Z., Bent, S.J., Shyu, C., Williams, C.J., Pierson, J.D., and Forney, L.J. 2008. Advances in the use of terminal restriction fragment length polymorphism (T-RFLP) analysis of 16S rRNA genes to characterize microbial communities. Appl. Microbiol. Biotechnol. 80: 365-380.

Sogin, M.L., Morrison, H.G., Huber, J.A., Welch, D.M., Huse, S.M., Neal, P.R., Arrieta, J.M., and Herndl, G.J. 2006. Microbial diversity in the deep sea and the underexplored "rare biosphere". PNAS. 103 (32):12115-12120.

Song, J., Weon, H.Y., Yoon, S., Hong., Park, D.S., Go, S.J., and Suh, J.W. 2001. Phylogenetic diversity of thermophilic actinomycetes and Thermoactino mycetes spp. Isolated from mushroom composts in Korea based on 16S rRNA gene sequence analysis. FEMS Microbiology Letters. 202: 97-102.

Takai, K., Nakagawa, S., Reysenbach, A. L. and Hoek, J. 2006. Microbial ecology of mid-ocean ridges and back-arc basins. in Back-Arc Spreading Systems: Geological,Biological, Chemical, and Physical Interactions. p. 185-213.

Takami, H., Inoue, A., Fuji, F., and Horikoshi, K. 1997. Microbial flora in the deepest sea mud of the Mariana Trench. FEMS Microbiol Lett. 152: 279-285.

Toffin, a.L., Webster, G., Weightman, A.J., Fry, J.C., and Prieur, D. 2004. Molecular monitoring of culturable bacteria from deep-sea sediment of the Nankai Trough, Leg 190 Ocean Drilling Program. FEMS Microbiology Ecology. 48: 357-367.

Winn, C.D., Cowen, J.P., and Karl, D.M. 1995. Microbes in deep-sea hydrothermal plumes, p. 255-273. In Karl, D. M. (ed.), The microbiology of deep-sea hydrothermal vents. CRC Press, Inc., Boca Raton, Fla.

Xiang, S.R., Yao, T.D., An, L.Z., Xu, B.Q., Li, Z., Wu, G.J., Wang, Y.Q., Ma, S., and Chen, X.R. 2004. Bacterial 
diversity in malan ice core from the Tibetan Plateu. Folia Microbiol. 49 (3): 269-275.

Yayanos, A.A., Dietz, A.S., and Van Boxtel, R. 1981. Obligately barophilic bacterium from the Mariana Trench. Proc. Natl. Acad. Sci. 78: 5212-5215.

Yoza, B.A., Harada, R.M., Nihous, G.C., Li, Q.X., and Masutani, S.M. 2007. Impact of mariculture on microbial diversity in sediments near open ocean farming of Polydactylus sexfilis. Ecological Indicators, 7: $108-122$.

Zeng, Z., Xiao, X., Wang, P., and Wang, F. 2004. Screening and characterization of psychrotrophic, lipolytic bacteria from deep-sea sediments. J. Microbiol. Biotechnol. 14: 952-958.
Zhang, R., Thiyagarajan, V., and Qian, P.Y. 2008. Evaluation of terminal-restriction fragment length polymorphism analysis in contrasting marine environments. FEMS Microbiology Ecology. 65: 169178.

Zhou, J., Bruns, M.A., and Tiedje, J. M. 1996. DNA recovery from soils of diverse composition. Applied and Environmental Microbiology. (62): 316-322.

Zilda, D.S., Patantis, G., and Chasanah, E. 2009. The use of restriction fragment length polymorphism (RFLP) technique for assessing genetic diversity of thermophilic bacteria. Journal of Marine and Fisheries Postharvest and Biotechnology. 4: 37-43. 
Squalen Vol. 7 No. 1, May 2012: 19-27. 